\title{
What is a firm? A reply to Jean-Philippe Robé
}

\author{
Simon Deakin ${ }^{1}$, David Gindis ${ }^{2}$ and Geoffrey M. Hodgson ${ }^{3}$ \\ 1. Faculty of Law and Centre for Business Research, University of Cambridge, Cambridge, UK \\ 2. Hertfordshire Business School, University of Hertfordshire, Hatfield, UK \\ 3. Loughborough University London, Institute of International Management, Stratford, London, UK
}

10 May 2021

For the Journal of Institutional Economics

KEY WORDS: firms, theory of the firm, business corporations, legal personality, legal institutionalism

JEL classifications: B52, D20, K10, L20

\begin{abstract}
In his recent book on Property, Power and Politics, Jean-Philippe Robé makes a strong case for the need to understand the legal foundations of modern capitalism. He also insists that it is important to distinguish between firms and corporations. We agree. But Robé criticizes our definition of firms in terms of legally recognized capacities on the grounds that it does not take the distinction seriously enough. He argues that firms are not legally recognized as such, as the law only knows corporations. This argument, which is capable of different interpretations, leads to the bizarre result that corporations are not firms. Using etymological and other evidence, we show that firms are treated as legally constituted business entities in both common parlance and legal discourse. The way the law defines firms and corporations, while the product of a discourse which is in many ways distinct from everyday language, has such profound implications for the way firms operate in practice that no institutional theory of the firm worthy of the name can afford to ignore it.
\end{abstract}




\section{Introduction}

In his interesting and forceful book on Property, Power and Politics, Jean-Philippe Robé (2020) argues that a broadly institutionalist theory of law and the economy is needed for an understanding of the structure and dynamics of power in the modern world. We are very sympathetic to this argument, having previously argued that in modern economies the law plays a vital role (Deakin, 2012a, 2012b; Deakin et al., 2017; Gindis, 2009, 2016; Hodgson, 2002, 2015a). At the same time, we note that Robé criticizes our definition of the firm as an individual or organization with the legally recognized capacity to produce goods or services for sale (Deakin et al., 2017). In this paper we defend our definition as a useful, and arguably essential, step in advancing an institutional understanding of law's role in constituting the firm.

Robé has for some years now attacked the practice of treating firm and corporation as synonymous and maintained that there is a vital need to differentiate the two (Robé, 2011, 2020). The firm, from his perspective, is an organized economic activity, not to be confused with the corporation, which is the legal instrument used to structure that activity, particularly by firms of a certain size. Robé chastises others, including the present writers, for failing to adhere religiously to this distinction. We agree that the two terms do not have the same meaning and are often conflated or confused. We also agree that, at least as a first approximation, a firm is an economic phenomenon and the corporation a legal form.

Since we do not claim that firm and corporation are the same thing, Robé must disagree with the way we differentiate the two terms. Our definition draws attention to the fundamental connections between the economic and legal aspects of firms. It emphasizes the legal features of firms that are overlooked in the various narratives in the theory of the firm (see the contributions collected in Langlois et al., 2002). Robé goes down a different path. He defines the firm as an organized economic activity which cannot be reduced to the legal notion of the corporation, and argues that while the law recognises, indeed creates, the category of the corporation, it does not recognise the firm. He furthermore claims that our definition fails to account for both the sole proprietorship and the multinational enterprise, and implies that employees cannot be part of the firm in the sense that we have defined it. We respond to each of these objections here.

In the process, we show that Robé's definition of the firm as an activity, albeit an organized one, raises problems of its own. There are also difficulties with his narrowly legalistic view of the corporation. An important implication of his position is that by insisting that firms are not corporations, Robé implies that corporations are not firms. This is an unwarranted departure from a commonplace taxonomy used by social scientists and business practitioners, according to which (business) corporations are types of (business) firms.

\section{The problem of definition in a multidisciplinary context}

Part of the issue at hand has to do with the crossing of disciplinary boundaries. It is not surprising that lawyers and economists attach slightly different meaning to key terms. Institutional economists wishing to understand the role the law plays in framing, guiding and impelling much economic activity should learn from law and import some legal ideas and meanings into economics, where they are useful (Cole and Grossman, 2002; Hodgson, $2015 b)$. Take the term corporation. Economists and other social scientists have much to learn from lawyers here. The notions of legal incorporation and legal personality have important economic, social and political effects, as Robé demonstrates. 
But just as there is a danger that economics, as a discipline, ignores legal phenomena or downplays legal understandings, there is a danger that law, as a discipline, takes too narrow a focus and remains blind to some aspects of socio-economic existence. Although Robé does not look at everything in terms of legal categories alone, he thinks that a strictly legalistic definition of the corporation avoids the confusion between firm and corporation. Our position is that the term corporation is not the sole property of lawyers (Deakin, 2019). Indeed, given that it also appears in different guises according to legal context, the term corporation is not even the exclusive property of corporate law (Deakin, 2012a, 2012b). But the key point we wish to emphasize here is that there is more besides legal rules and procedures to business corporations. In a social science context, given the political, economic, ethical and cultural aspects involved, we cannot understand them solely in legal terms.

The term firm is likewise not the sole property of economists, but the problems the term raises are different. While it is the focus of an extensive literature in economics, there is a lamentable absence of consensus regarding the definition of the firm (Gindis, 2016; Hodgson, 2019). We must therefore consider additional sources. The term's usage in law is somewhat marginal. The English practice of calling certain partnerships 'firms' has died out. But the absence of a technical definition of firm in law does not imply that the law is blind to the firm or that it plays no part in facilitating the firm's existence.

When the European legal mind thinks of the enterprise as an economic entity which brings together human, physical and intellectual assets in a 'going concern', this idea is expressed by the notion of the undertaking, and the further idea of the establishment gives some sense of the enterprise as a geographical space or set of locations (Deakin, 2003). In practice, these notions exist to give effect to certain regulatory purposes connected to labour and competition law (if those bodies of law did not exist in something like their current form, there would be no need for such terms).

This is a reminder that legal concepts do not exist to describe the world, but to order it. That the corporation and not the enterprise is the principal legal concept used to order the business firm in some jurisdictions, particularly those of Anglo-American common law, is a sign of the priority which corporate law tends to give to financial interests over productive ones. At the same time, it should be noted that corporate law is not the whole of the law governing business firms, and that labour law and tort law see the enterprise somewhat differently, as 'a mechanism for absorbing, controlling and spreading social and economic risks' (Deakin, 2003,112 ). This underscores the fact that while the firm is not described by a legal category, law does not ignore its socio-economic or legal impact.

Although it is instructive to consider various legal discourses on the firm which have existed over time and can be currently observed, no dominant conception of the firm emerges. Other disciplines and discourses can and should be called in aid. We should do well to appreciate how the term is used in business studies and other social sciences, and we must also consider how the term is used more broadly in society.

When there is need to draw from multiple disciplines in defining a term and understanding the phenomenon to which it refers, it is very important to note the different meanings which a term may have in different disciplinary domains, and to seek to identify any common or functionally equivalent elements of those meanings. We should in particular avoid a counsel of perfection that insists that exact meanings in one discipline must always apply without modification to another (Deakin, 2019). When lawyers engage in conversation with (other) social scientists, they should resist the temptation to say that theirs are the correct or definitive definitions; but the observation cuts both ways. Being able to agree on definitions, including 
their differences as well as any common elements across multiple disciplines, is important because, in the final analysis, science is an institutionalized social process: researchers must come to some workable agreement about the objects of their investigation, so that they can establish a division of labour for their shared enquiry (Polanyi, 1962).

Taxonomies matter critically for the social sciences and for the implementation of their insights in applied disciplines such as law and management. Taxonomic definitions are tools to differentiate one class of real-world phenomena from another. There is no easy formula for creating or adjudicating over such definitions. They are subject to ongoing conversation and revision. But while there is no tidy end point, there are some basic rules and guidelines (Hodgson, 2019). The first (advisory rather than compulsory) rule in the construction of taxonomic definitions is that they should where possible be close everyday meanings (Robinson, 1950). Scholars from Aristotle to Carl Menger and Alfred Marshall proffered this advice (Hodgson, 2019). ${ }^{1}$ Because language is social and interpersonal, individuals cannot change meanings at will. Words have more power over individuals than individuals have power over the meanings of words. Consequently, it is important to be careful in positing atypical or counter-intuitive definitions - they can create confusion and obstruct academic progress.

\section{Everyday meanings of firm and corporation}

With these guidelines in mind, let us briefly examine the etymology and modern usage of the word firm. The Chambers Dictionary of Etymology notes the origin of the meaning of firm as a 'business concern', recording its emergence in English in 1744 to refer to 'a company ... borrowed from German Firma a business or name of business, originally signature, from Italian firma signature, from firmare to sign' (Barnhart, 1988, 384-5).

A narrower meaning of a firm as a 'partnership' has a special colloquial application to legal or medical partnerships, as in the film The Firm, starring Tom Cruise. But dictionaries typically carry a broader meaning as well. The Merriam-Webster Online Dictionary notes a narrower meaning in terms of a 'partnership' and a broader meaning as 'a business unit or enterprise' (Merriam-Webster, 2021). Accordingly, the online Collins Dictionary regards the firm as meaning 'a business partnership' or 'any business enterprise' (Collins, 2021). The online Cambridge Dictionary sees a firm as 'a company or business' (Cambridge University Press, 2021). ${ }^{2}$

As Robé (2020: 13) notes, the term company is also sometimes used as a synonym of corporation. English 'company law', for example, is functionally equivalent to US 'corporate law'. American lawyers operating in the UK would not be misunderstood if they were to say corporation instead of company. But while they are sometimes used interchangeably, the two terms come from different sources and sometimes (in other contexts) have different meanings. In addition, the meaning of company in English law has shifted.

\footnotetext{
1 Marshall (1920) did not follow his own advice when he defined, following most other economists since Adam Smith, the term capital in terms of factor inputs, rather than the money-related meaning used in business and accounting, with possible adverse consequences (Hodgson, 2014, 2015a). By contrast, Menger (1888) dissented from this Smithian usage (Braun, 2020).

${ }^{2}$ It is perhaps not surprising that the British royal family is sometimes referred to as 'the firm'.
} 
The term company has not always been associated with incorporation if that is taken to mean a legal act involving the creation of a new juridical person. It was the term used to describe the trading entities which emerged in Florence and Genoa in the 12th century, when several individuals - typically from one family -agglomerated their capital by establishing a partnership with unlimited and joint liability (Greif, 1996; Harris, 2020). The notion of corporation comes from a different source. It was originally applied to medieval entities such as towns, monasteries, guilds, charities and universities, long before it became widely established in a business context.

Before accessible procedures for legal incorporation were introduced in the UK in the 19th century, most business firms lacked legal personality and were organized using a legal form that was a hybrid of the partnership and the trust (Stern, 2017). Although it was founded upon the partnership principle of trading on a joint account, the joint stock company was distinguished from the ordinary partnership on the basis of its economic, rather than its legal, characteristics (Ireland, 1999). Later, particularly after the spread of general incorporation laws allowed companies to transform into corporations, these two terms moved closer in meaning, and were then used quasi-interchangeably among Anglophone lawyers. But ambiguities and differences still persist.

Although company and corporation can be used as synonyms in the legal context, there is also an everyday association in the English language between company and firm. There are two rival terminological associations - company and firm, and company and corporation which pull the term company in different directions and establish a conceptual link between firm and corporation.

Robé is right to observe that these words are sometimes used interchangeably. When little of substance turns on the matter, this practice is justifiable. But it is significant that when firm is invested with discipline-specific meanings, the particular aspects that are highlighted often remain anchored in the ordinary language meaning of the term. As Fritz Machlup (1967: 268) famously noted, in management, accounting, law and statistics, the firm can be defined in many different ways: as 'cooperative system with authoritative coordination', 'decisionmaking system for typical business operations', 'collection of assets and liabilities', 'juridical person with property, claims, and obligations', and 'business organization under a single management or a self-employed person with one or more employees or with an established place of business.' Distinct as these definitions are, they are all linked to the ordinary language understanding of the firm as an identifiable business unit.

Various definitions to be found in the theory of the firm literature also remain anchored in the ordinary meaning of firm. Ronald Coase's $(1937,393)$ suggestion that a firm is a 'system of relationships which comes into existence when the direction of resources is dependent on the entrepreneur', Oliver Williamson's $(1985,73)$ analysis of firms as 'unified governance structures', Sanford Grossman and Oliver Hart's $(1986,693)$ characterization of the firm as a 'single ownership unit', or Bengt Holmstrom and Paul Milgrom's (1994) work on the 'firm as an incentive system', all clearly relate to the idea of a singular business unit.

The intent of such definitions is broadly taxonomic, in the sense that they are formulated in the spirit of Coase's $(1937,389)$ important assertion that 'the distinguishing mark of the firm is the supersession of the price mechanism'. This distinguishes markets from both all economic forms of the firm (including entrepreneurial, managerial or cooperative firms) and all legal forms of the firm (including sole proprietorships, partnerships, companies and business corporations). All of these can be placed within the same taxonomic class. 


\section{Differentiating firm and corporation}

For Robé (2020, 195), firm and corporation are 'radically different notions': 'A firm is an organization performing an economic activity. A corporation is a type of legal person - most firms of some significance being organized using business corporations.' Elsewhere, Robé $(2020,210)$ defines the firm in slightly different terms as an 'organized economic activity' (see also Robé, 2011, 3). The two definitions may seem fairly similar, and Robé seems to use them interchangeably, but they are not identical. The first treats the firm as an organization, the second as an activity. Regardless, Robé (2020, 196 n.) clarifies that he is working primarily with the latter concept.

Treating the firm as an activity, albeit an organized one, is unsatisfactory, for at least two reasons. The first is that there is no case, from etymology or common usage, to support this stipulation. It is atypical and therefore violates the common-sense guideline for definitions outlined above. The second reason is that, conceptually, if the firm really is an activity, or always 'performing an economic activity', then it ceases to exist when those activities cease, as would be the case when the firm shuts down overnight or on weekends or holidays. Robé's 'activity' formulations - including variations such as 'the firm is the process of coordinating various resource providers' (Robé, 2020, 199) - are flawed.

Contrary to Robé, our definition of the firm is rooted in the term's ordinary language meaning as a singular business unit. We define 'the term firm to apply to individuals or organizations with the legally recognized capacity to produce goods or services for sale' (Deakin et al., 2017, 194). On this definition, the firm does not cease to exist when trading or production temporarily ceases. Importantly, the definition applies to all the economic and legal forms of the firm and it also allows us to distinguish all these kinds of firms from markets.

A definition of the firm as an organized economic activity might conceivably apply to various kinds of firms, but it is difficult to see how it helps distinguish the firm from the market, since markets are arguably organized economic activity. Certainly, Robé's definition of the firm implies that some markets could be firms. While a firm might organize a market (many platform companies currently do this), and some market organizations (such as the London Stock Exchange) are legally incorporated, the two concepts remain distinct, even in this context. Similar difficulties are encountered when considering the other discrete structural alternatives studied in transaction cost economics, including various so-called 'hybrid forms' (Ménard, 2014, 2021). On Robé's definition, relational contracts between firms dissolve into relational contracts between organized economic activities. Defining the firm in terms of distinct legally recognized capacities avoids these conceptual tangles (Deakin et al., 2017; Hodgson, 2002).

These uncomfortable conclusions might be avoided if instead of defining the firm as an activity Robé were to stick to the definition of the firm as the organization performing that activity. This would still allow him to claim that 'firms are structured using corporations; they are not corporations' (Robé, 2011, p. 7). It is important to note that the second part of this formulation could be read as implying that the categories firm and corporation are mutually exclusive. If firms are not corporations, then corporations are not firms, they are merely legal instruments used to structure a firm's affairs. The problem here is that if a firm is an organization, and many firms are 'organized' using (legal) corporations, then a (business) corporation is a specific mode of organization, and not just a legal instrument. To confine the 
term corporation to its strictly juridical meaning when everyday discourse and other disciplines are using it in a broader sense is going to create difficulties.

Robé clams that a corporation is a legal instrument used to structure most firms of some significance. We do not disagree. Robé $(2020$, p. 192) is also undoubtedly right to say that "business corporations have what is called a "legal personality": they are treated by the legal system as "persons" in a position to own assets, contract and be liable for the torts that are imputed to them'. We believe to have made this point ourselves. A central implication of our definition of firm, however, is that 'a corporation is a kind of firm' which 'has a structure as designated under corporate law' (Deakin et al., 2017, 194). It follows, as we immediately add, that 'all corporations', so defined, 'are firms, but not all firms are corporations'. Richard Adelstein (2013) and many other scholars working at the intersections of economics and law agree. This contrasts with Robé's argument that firms are not corporations. This, therefore, seems to be why Robé (2020, 196 n.) cites us as an example of 'the difficulty of convincing authors that it is fruitful to differentiate the two terms'. But perhaps we are not using the word differentiate in the same way.

\section{Digging deeper}

Robé argues that firm and corporation are more than just radically different notions - they denote radically different realities. As he puts it: "the firm ... has no existence at law (it is not a "fiction") whereas the corporation is a legal person entitled to operate in the legal system by owning, contracting, suing and being sued; and it is subject to the laws and regulations of the legal system' (Robé, 2012, 8). Firms 'do not exist in contemplation of the law as persons; they do not have rights and, conversely, they cannot incur liabilities' (Robé, 2020: 223-224). Indeed: 'The firm ... is neither a legal object nor a legal subject. It does not operate in the legal system' (Robé, 2012, 8). From the strictly legalistic point of view, these statements do not seem objectionable. But of course that depends on how firm is defined and whether it is legitimate to regard a corporation as a type of firm. In any case, the suggestion that the firm cannot ever be a legal 'object' is contradicted by the use of the term undertaking in contemporary labour and competition law.

Robé's language is strikingly similar to Michael Jensen and William Meckling's (1976) influential discussion of the firm, but his argument is actually directed against their definition of 'the private corporation or firm is simply one form of legal fiction which serves as a nexus for contracting relationships' (Jensen and Meckling, 1976, 310). ${ }^{3}$ For Robé (2011, 2012, 2020), this unwarranted conflation of firm and corporation invites us to ignore the way that corporate law structures the business firm. Jensen and Meckling, following Friedman (1970), invite us to reduce the firm to a set of contractual relationships, with the focus on those between 'owners' and managers, as if shareholders 'own' the firm or the corporation (Friedman explicitly, and Jensen and Meckling impliedly, conflate these terms when it comes to determining ownership), as well as the assets which are placed under the managers' delegated authority.

This view, which has been instrumental in (mis-)shaping corporate law and the corporate governance debate of the last few decades, is one that Robé, along with others (e.g., Stout, 2012; Ciepley, 2020), seeks to undermine. We are sympathetic to this position and have argued along these lines ourselves (Deakin, 2012a, 2012b; Hodgson, 2015a; Deakin et al.,

\footnotetext{
${ }^{3}$ See Gindis (2020a) on the origins, meaning and influence of Jensen and Meckling's definition of the firm.
} 
2017). We agree with Robé that the firm in its totality, including the human beings who work in it, cannot be owned. ${ }^{4}$ Nor can the corporation, as a legal person, be owned. In both cases, 'ownership' refers, critically, to a category of claim which the law recognises as such. Just as it is vital not to conflate firm and corporation, it is vital also not to conflate 'ownership', a legal construction, with physical possession (Honoré, 2013). At this point, economics needs to take account of legal reality: given the material significance of the way in which the legal system supports certain ownership claims, and not others, it is a fundamental error for economics, in so far as it purports to be a science of human behaviour, to assert that shareholders 'own' either the firm, the corporation, or its assets.

What then is the significance for economics, and other social sciences, of legal definitions of the business firm? Those definitions operate on more than one level. For lawyers, they frame the way in which judges and other legal practitioners apply legal rules to resolve disputes, settle claims, and more generally order the way in which business is conducted. For business actors (investors, managers, workers, creditors, and so on), legal rules, which are ultimately enforced by the power of the state, have material consequences. The law affects the value of claims, shapes expectations, and channels behaviour.

This is why we defined the term firm in terms of legally recognised capacity (Deakin et al 2017, 194). This is not the same thing as saying that the firm as such has legal personality; nor does our definition make the firm "synonymous with the concept of "legal entity" (Robé, 2020, $196 \mathrm{n}$ ). Whether or not a firm is legally structured as a corporation (which must have legal personality), a partnership (which may or may not have it, depending on circumstances) or some other kind of legal entity, its ability to function as a productive unit is unavoidably bound up with the way the law works. The law of the business firm (which as we have noted is not confined to corporate or company law) is so deeply imbricated with the operation of firms in the economy that it makes no sense for the economist's conception of the firm to ignore the role of the law; hence our claim that a productive entity which is not 'legally structured' is not 'in economic or other terms, a firm' (Deakin et al, 2017, 198).

Economists need to take note of the fact that even firms that formally lack legal personality need the law to function. What we referred to as the 'legally recognised capacity' can take many forms. In the case of the (unincorporated) general partnership, for example, some or all partners may be empowered (by their partnership agreement) to act and make agreements in the name of the partnership as a whole. This includes agreements with input suppliers as well as agreements with customers. Consequently, rights and liabilities will accrue to the partnership itself, and courts will more often than not recognize this when they are asked to adjudicate disputes with third parties. Furthermore, as Henry Hansmann and others have shown, courts have also long recognized a certain degree of separation between partnership assets and the partners' personal assets, which in liquidation grants firm creditors priority over personal creditors in the division of firm assets (Hansmann and Kraakman, 2000; Hansmann et al., 2006; Gindis, 2020b). The partnership is thus legally recognized as such.

\section{Sole proprietorships}

\footnotetext{
4 Thus the legal notion of undertaking, in so far as it denotes a legal object or res which can be alienated by one employer to another, does not include the employees, who cannot be bought or sold, and hence compulsorily transferred along with the physical and intellectual assets of the firm (Adams et al., 2021, 219-220).
} 
According to Robé (2020, 196 n), a defect of our use of firm to refer to individuals or organizations with the legally recognized capacity to produce goods or services for sale is that 'an individual person can be a "firm".' Robé is making two different points. The first is that while 'a firm can be created by a single individual person', in which case 'an individual legal person contracts with suppliers ... and will organize the manufacturing of products or the delivery of services', this does not alter the fact that 'the individual organizing the operation of this economic activity is not "the firm". The organized economic activity is' (Robé, 2020, 199). His second point implicitly targets our suggestion that 'an entrepreneur ... become[s] a firm upon the acquisition of a legally-recognized separate legal personality' (Deakin et al., 2017: 197).

Setting aside the flawed activity-based view of the firm, Robé is of course correct that a firm can be created by a single individual. Our definition covers this possibility, so this leaves Robé's second point, which is that our understanding of firm leads us to effectively exclude 'the business created by an individual entrepreneur not using a separate legal vehicle to structure his business' (Robé, 2020, 207). For Robé, the existence of sole proprietorships, which are legally indistinguishable from the individuals operating them, shows that there is no necessary link between firms and separate legal personality.

While our definition clearly includes single-person companies, the sole proprietorship may seem to be more problematic for it. In the case of the sole trader, there is often no clear legal boundary between personal and business assets. However, legal capacity is not exactly coterminous with the act of incorporation. Legal systems are capable of endowing certain organisations with the right to hold property, enter into contracts and to sue and be sued, which are the core components of legal capacity, in the absence of incorporation, as in the case of British trade unions (Adams et al, 2021, 724).

Similarly, businesses run by sole traders have an existence in law and so have some of the attributes of legal persons even if they are not companies. The emergent law of business associations was capable of distinguishing between the personal and business assets of merchants long before the widespread availability of incorporation through an act of legal registration (Hansmann et al., 2006). In today's law, the business operated by a sole trader is legally recognised in numerous ways. Trading income will be treated as distinct for tax purposes, and the individual operating the business may be classed as an undertaking for the purposes of competition law, while, conversely, falling outside the scope of labour law protections, such as minimum wage rules (Deakin, 2020). This is the sense in which even the sole proprietor has a legally recognised capacity to act as a business and to be taxed and regulated accordingly. It follows that the business of a sole trader acquires a kind of legal capacity and features of personhood, even in the absence of incorporation.

\section{Employees}

In another attempted rebuttal of our definition, Robé (2020, 196 n) notes that it leads to the 'strange consequence' that 'employees are not part of "firms"'. He does not specify what he means by 'part of', but the criticism seems to be that our definition misrepresents employees as being outside the boundaries of the firm when in reality 'employees are, of course, members of firms'. As Robé $(2011,39-40)$ puts it, 'in real firms ... there are employment contracts'. This objection stems from Robé's claim that we conflate firm and corporation: if a 
firm is just a legal person, in the sense of being just a nexus for contracting relationships, then employees (and other input owners) contract with it as outside parties. ${ }^{5}$

However, nothing in our use of the term firm to apply to individuals or organizations with the legally recognized capacity to produce goods and services for sale justifies this interpretation. Our view does not preclude the idea that employees and the organizational structures within which they are placed are important for firms and can therefore be 'part of' firms in some meaningful sense. Perhaps, though, Robé is making a deeper point. In Coasean fashion, he appears to see employment relationships as essential to the organization of economic activity within firms, which is to say that he views employees as essential to the nature and existence of firms.

From this point of view, the firm, as an organized economic activity, comes into existence once the productive activities of employees are organized by an entrepreneur (Robé, 2020, 208), and it may then make sense to classify employees, contrary to other input providers, as members of the firm (Robé, 2011, 41). We understand that this is an important piece of Robé's larger project of reorienting the corporate governance debate away from its quasiexclusive focus on shareholders and managers. We have no disagreement this project and regard it as important. However, it may be going too far to say that businesses without employees are not firms.

Statistics collected by governments and various other agencies record that most businesses do not in fact have any employees. In the UK, for example, about $76 \%$ of the firms making up the business population have no employees (Department of Business, Energy and Industrial Strategy, 2020). Non-employer enterprises similarly account for the bulk of registered firms in many other economies (OECD, 2017). Of course, these non-employing businesses do not constitute more than a small fraction of the total size of the business population if we measure it by output or value. That said, the prevalence of these types of businesses suggests that a definition of firm that depends on the presence of employees may be unduly narrow.

It is also possible, of course, for there to be companies (as opposed to businesses) which do not have any employees because they do not trade. This includes companies set up solely for the purposes of holding certain assets, for reasons of tax 'efficiency' or arbitrage, among others (Pistor, 2019). These companies are not firms in any real sense of the term, and our definition of the firm as a legally constituted entity set up for the production and sale of goods and services does not require us to treat them as such.

\section{Multinationals}

The major part of Robé's (2020) book, and indeed the primary focus of his work more generally, examines 'firms in the world power system'. According to Robé, this is the setting in which our definition of the firm runs into the biggest problems. As he explains, a disturbing implication of our definition of the firm in terms of legally recognized capacities is that "there can be no "multinational firms" since a multinational firm is not a "legal entity" (Robé, 2020, p. $196 \mathrm{n}$ ). This again depends on what we mean by firm, and whether it is legitimate to regard a corporation as a type of firm. But there an important point here, which is that while most large (and indeed, many small and medium-sized) enterprises are constituted as multi-

\footnotetext{
5 This is why Jensen and Meckling (1976, p. 311) observed that 'it makes little or no sense to try to distinguish those things which are "inside" the firm ... from those things that are "outside" of it.'
} 
corporate forms, there is no generally accepted legal concept of the corporate group which adequately captures this complex economic and social reality (Deakin, 2003).

Robé is absolutely correct that multinationals, as multi-corporate enterprises, do not have a single (global) legal personality but instead operate through separately incorporated firms in multiple countries. Even in the case of a corporate group or a conglomerate operating within a single country, as Philip Blumberg (1993) pointed out, the breakdown of the straightforward link between a singular economic entity and a singular legal entity poses a challenge to both the theory of the firm and corporate law theory. The problem may be compounded when corporate groups have foreign subsidiaries, but in the context of the present debate, this seems incidental. After all, regardless of the country in which it is incorporated, a national subsidiary of a multinational enterprise may well be operating as a singular firm. Each such a subsidiary would have legally recognized capacities which enable it to produce goods and services for sale.

It follows, we believe, that the existence of corporate groups operating nationally or internationally does not significantly diminish the value of our definition of the firm. Instead of pushing us to revisit the definition of the firm, the reality of corporate groups and multinationals ought to push us in the opposite direction. We need different terms to account for different realities (Hodgson, 2002, 2015; Gindis, 2009). We need to have a definition of multinational enterprise alongside a definition of firm.

We also need to appreciate that the definition of the former must rest on the definition of the latter. As Reinier Kraakman (2001) argued, the existence of corporate groups, multinational enterprises, networks and other complex economic organizations, including those which Claude Ménard (2021) calls 'hybrid forms', does not displace the importance of legal form to the structuring of business; it reinforces it. Hence to use the multinational enterprise as a counterexample to our definition of the firm misses the mark completely.

\section{Concluding remarks}

In summary, Robé's (2020) book contains valuable insights and addresses vital issues, but his objections to our proposed use of the term firm to apply to individuals or organizations with the legally recognized capacity to produce goods or services for sale are unsuccessful. We agree with Robé that firm and corporation have different meanings. But we do not believe that they are mutually exclusive categories. We are not convinced that one should refrain from viewing corporation as a type of firm. Business corporations are incorporated firms.

A good reason to retain this taxonomy is that its use is widespread among social scientists and business practitioners. In addition, it conveys an important analytic message: just as firms are both economic and legal phenomena, corporations are also both economic and legal phenomena. Treating firm as a purely economic phenomenon and corporation as just a legal term of art is unsatisfactory. Both moves may prevent us from seeing how economic and legal mechanisms hang together.

Like Robé, we are interested in what Warren Samuels (2007) referred to as the 'legaleconomic nexus'. Unlike Robé, we are not prepared to accept the kind of strict separation between economic and legal phenomena that underpins his approach to the firm. In our version of legal institutionalism, economic and legal phenomena do not exist in separate ontological planes or spheres. Law is a part of social reality; it constitutes and constrains, liberates and regulates. No institutional theory of the firm, an no institutional theory of capitalism more generally, is worthy of the name if it overlooks the role of law. 


\section{References}

Adams, Zoe, Barnard, Catherine, Deakin, Simon, and Fraser Butlin, Sarah (2021) Deakin and Morris' Labour Law, $7^{\text {th }}$. ed. (Oxford: Hart).

Adelstein, Richard P. (2013) 'Firms as Persons', Cahiers d'économie politique, 65: 161-182.

Barnhart, Robert K. (ed.) (1988) Chambers Dictionary of Etymology (Edinburgh and New York: Chambers Harrap).

Blumberg, Philip I. (1993) The Multinational Challenge to Corporation Law: The Search for a New Corporate Personality (Oxford and New York: Oxford University Press).

Braun, Eduard (2020) 'Carl Menger: Contribution to the Theory of Capital (1888), Section V', Journal of Institutional Economics, 16(4): 557-568.

Cambridge University Press (2021) 'Firm', in Cambridge Dictionary (Cambridge: Cambridge University Press), online at: https://dictionary.cambridge.org/dictionary/english/firm. Retrieved 5 Feb 2021.

Ciepley, David (2020) 'The Anglo-American Misconception of Stockholders as "Owners" and "Members": Its Origins and Consequences', Journal of Institutional Economics, 16(5): 623-642.

Coase, Ronald H. (1937) 'The Nature of the Firm', Economica, 4(16): 386-405.

Cole, Daniel H. and Grossman, Peter Z. (2002) 'The Meaning of Property Rights: Law versus Economics?' Land Economics, 78(3), August, pp. 317-330.

Collins (2021) 'Firm' in Collins Dictionary, online at: https://www.collinsdictionary.com/dictionary/english/firm. Retrieved 5 Feb 2021.

Deakin, Simon (2003) 'Enterprise-Risk: The Juridical Nature of the Firm Revisited', Industrial Law Journal, 32, 97-113.

Deakin, Simon (2012a) 'The Juridical Nature of the Firm', in Thomas Clarke and Douglas Branson (eds) (2012) The Sage Handbook of Corporate Governance (London: Sage), pp. $113-35$

Deakin, Simon (2012b) 'The Corporation as Commons: Rethinking Property Rights, Governance and Sustainability in the Business Enterprise', Queen 's Law Journal, 37(2): 339-381.

Deakin, Simon (2019) 'Juridical Ontology and the Theory of the Firm', in Francesca Gagliardi and David Gindis (eds) (2019) Institutions and Evolution of Capitalism: Essays in Honour of Geoffrey M. Hodgson (Cheltenham UK and Northampton MA: Edward Elgar), pp. 12741.

Deakin, Simon (2020) 'Decoding Employment Status', King’s Law Journal, 31(2), 180-193.

Deakin, Simon, Gindis, David, Hodgson, Geoffrey M., Huang, Kainan, and Pistor, Katharina (2017) 'Legal Institutionalism: Capitalism and the Constitutive Role of Law', Journal of Comparative Economics, 45(1): 188-200.

Department of Business, Energy and Industrial Strategy (2020) 'Business Population Estimates for the UK and the Regions 2020' (London: UK Government National 
Statistics). https://www.gov.uk/government/statistics/business-population-estimates-2020. Retrieved 8 February 2021.

Friedman. Milton (1970) 'The Social Responsibility of Business is to Enhance its Profits', New York Times Magazine, 13 September, 32-33, 122-126.

Gindis, David (2009) 'From Fictions and Aggregates to Real Entities in the Theory of the Firm', Journal of Institutional Economics, 5(1): 25-46.

Gindis, David (2016) 'Legal Personhood and the Firm: Avoiding Anthropomorphism and Equivocation', Journal of Institutional Economics, 12(3): 499-513.

Gindis, David (2020a) 'On the Origins, Meanings and Influence of Jensen and Meckling's Definition of the Firm', Oxford Economic Papers, 72(4): 966-984.

Gindis, David (2020b) 'Ernst Freund as a Precursor of the Rational Study of Corporate Law', Journal of Institutional Economics, 16(5): 597-621.

Greif, Avner (1996) 'The Study of Organizations and Evolving Organizational Forms Through History: Reflections from the Late Medieval Family Firm', Industrial and Corporate Change, 5(2): 473-501.

Grossman, Sanford and Hart, Oliver D. (1986) 'The Costs and Benefits of Ownership: A Theory of Vertical and Lateral Integration', Journal of Political Economy, 94(4): 691-719.

Hansmann, Henry and (2000) 'The Essential Role of Organizational Law', Yale Law Journal, 110(3): 387-440.

Hansmann, Henry, Kraakman, Reinier R. and Squire, Richard (2006). Law and the Rise of the Firm', Harvard Law Review, 119(5): 1333-1403.

Harris, Ron (2020), Going the Distance: Eurasian Trade and the Rise of the Business Corporation, 1400-1700, Princeton, NJ: Princeton University Press.

Hodgson, Geoffrey M. (2002) 'The Legal Nature of the Firm and the Myth of the FirmMarket Hybrid', International Journal of the Economics of Business, 9(1): 37-60.

Hodgson, Geoffrey M. (2014) 'What is Capital? Economists and Sociologists have Changed its Meaning - Should it be Changed Back?' Cambridge Journal of Economics, 38(5): 1063-86.

Hodgson, Geoffrey M. (2015a) Conceptualizing Capitalism: Institutions, Evolution, Future (Chicago: University of Chicago Press).

Hodgson, Geoffrey M. (2015b) 'Much of the "Economics of Property Rights" Devalues Property and Legal Rights', Journal of Institutional Economics, 11(4): 683-709.

Hodgson, Geoffrey M. (2019) 'Taxonomic Definitions in Social Science, with Firms, Markets and Institutions as Case Studies', Journal of Institutional Economics, 15(2): 207-33.

Holmström, Bengt and Milgrom, Paul (1994) 'The Firm as an Incentive System', American Economic Review, 84(4): 972-991.

Honoré, Anthony M. (2013) 'Ownership', Journal of Institutional Economics, 9(2), 227-255 (originally published as: 'Ownership', in A.G. Guest (ed.) Oxford Essays in Jurisprudence, Oxford: Clarendon Press, 1961.

Ireland, Paddy W. (1999) 'Company Law and the Myth of Shareholder Ownership', Modern Law Review, 62(1): 32-57. 
Jensen, Michael C. and Meckling, William H. (1976) 'Theory of the Firm: Managerial Behavior, Agency Costs and Ownership Structure', Journal of Financial Economics, 3(4): 305-60.

Kraakman, Reinier R. (2001) 'The Durability of the Corporate Form', in Paul DiMaggio (ed.), The Twenty-First-Century Firm: Changing Economic Organization in International Perspective (Princeton, NJ: Princeton University Press), pp. 147-160.

Langlois, Richard N., Yu, Tony F.-L. and Paul L. Robertson, eds (2002) Alternative Theories of the Firm, 3 vols (Cheltenham UK and Northampton MA: Edward Elgar).

Machlup, Fritz (1967) 'Theories of the Firm: Marginalist, Behavioral, Managerial', American Economic Review, 57(1): 1-33.

Marshall, Alfred (1920) Principles of Economics: An Introductory Volume, 8th edn. (London: Macmillan).

Ménard, Claude (2014) 'Embedding Organizational Arrangements: Toward a General |Model', Journal of Institutional Economics, 10(4): 567-89.

Ménard, Claude (2021) 'Hybrids: Where Are We?', Journal of Institutional Economics, published online: doi:10.1017/S1744137421000230/.

Menger, Carl (1888) 'Zur Theorie des Kapitals', Jahrbücher für Nationalökonomie und Statistik, 17: 1-49.

Merriam-Webster (2021) 'Firm', in Merriam-Webster Online Dictionary, online at: https://www.merriam-webster.com/dictionary/firm. Retrieved 5 Feb 2021.

OECD (2017) Entrepreneurship at a Glance 2017 (Paris: OECD Publishing).

Pistor, Katharina (2019) The Code of Capital: How the Law Creates Wealth and Inequality (Princeton, NJ: Princeton University Press).

Polanyi, Michael (1962) 'The Republic of Science: Its Political and Economic Theory', Minerva, 1(1): 54-73.

Robé, Jean-Philippe (2011) 'The Legal Structure of the Firm', Accounting, Economics and Law, 1(1), Article 5, pp. 1-86.

Robé, Jean-Philippe (2012) 'Being Done with Milton Friedman'. Accounting, Economics and Law, 2(2): 1-33.

Robé, Jean-Philippe (2020) Property, Power and Politics: Why We Need to Rethink the World Power System (Bristol: Bristol University Press).

Robinson, Richard (1950) Definition (Oxford: Clarendon Press).

Samuels, Warren J. (2007). The Legal-Economic Nexus (New York: Routledge).

Stern, Philip J. (2017) 'The Corporation in History', in Grietje Baars and André Spicer (eds) The Corporation: A Critical, Multi-Disciplinary Handbook (Cambridge: Cambridge University Press), pp. 21-46.

Stout, Lynne A. (2012) The Shareholder Value Myth: How Putting Shareholders First Harms Investors, Corporations and the Public (San Francisco: Berrett-Koehler).

Williamson, Oliver E. (1985) The Economic Institutions of Capitalism: Firms, Markets, Relational Contracting (London and New York: Free Press and Macmillan). 